\title{
Urban Environmentalism and Activists' Networks in China: The Cases of Xiangfan and Shanghai
}

\author{
Lei Xiea,\# and Peter Hob,c \\ ${ }^{\text {a}}$ Policy Studies Institute, 50 Hanson Street, London W1W 6UP, UK \\ ${ }^{\mathrm{b}}$ College of Humanities and Development, China Agricultural University, \\ No. 2, Yuanmingyuan West RD, Beijing 10094, Peoples Republic of China \\ ${ }^{\mathrm{C}}$ International Development Studies, Faculty of Spatial Sciences, University of Groningen, \\ Dierenriemstraat, 100, 9742 AK, Groningen, The Netherlands \\ \#Corresponding author. E-mail: lei.xieavoine@gmail.com
}

\begin{abstract}
Despite China's repressive environment, the public, organised by environmental non-governmental organisations (ENGOs), are represented in local environmental governance; their voices are articulated and policy-making is affected. Empirical findings from ENGOs in two Chinese cities demonstrate that environmental activism is not an activity with a fair degree of autonomy and self-regulation, but occupies a social space that is enmeshed in a web of interpersonal relations and informal/formal rules between political and social actors. Contextual factors of economic development, openness of the political system and local culture also have impacts on movement dynamics in different locations.
\end{abstract}

Keywords: environmental movement, personal network, ENGOs, campaign, China

\section{INTRODUCTION}

SINCE THE MID-1990s, a blossoming of environmental non-governmental organisations (ENGOs) has been witnessed in China. By participating in ENGOs and various citizen groups, the public has begun to play an increasingly critical role in Chinese environmental governance at various levels. While data are mostly unreliable and vary widely, some believe that until 2005, approximately 2000 environmental groups were officially registered as NGOs, with probably as many registered as for-profit business entities or not registered at all (Ho 2001; Economy 2005). The significant amount of unregistered environmental social organisations reflects the government's rather ambiguous attitude toward NGOs.

In terms of movement strategy and movement development, coordinated actions that are not completely in line with or fully supported by the government are difficult to be made. Special tactics are needed in protesting and campaigning activities that include using key figures and leaders' personal networks (Xie \& Mol 2006). This strategy seems crucial in organising environmental campaigns and obtaining various resources. While in the early stages of ENGO development (i.e. in the late 1960s and 1970s) in Western societies, personal and individual networks were also highly relevant as resources for movement formation, the fact that a large number of Chinese ENGOs rely strongly on personal connections of their leaders or key figures is not unlike their Western counterparts.

Yet, several key questions concerning Chinese environmental activism remain unclear. How do the environmental movement actors in China establish coordinated actions? Particularly, what role do personal networks play in this process? How do movement actors interact with political authorities and generate social influence in China's current political conditions? This article intends to analyse the characteristics of the Chinese environmental movement in terms of their organisational development and strategies. A comparative study of two Chinese cases is conducted to illustrate the dynamics of environmental activism and how they are affected by the social contexts based on their location.

\section{FORMALISATION AND THE FORMATION OF THE CHINESE ENVIRONMENTAL MOVEMENT}

Major social movement theories have raised different views on social movement organisations' (SMOs) forms and their development in collective actions. In this sec-

Copyright: (C Xie and Ho 2008. This is an open access article distributed under the terms of the Creative Commons Attribution License, which permits unrestricted use and distribution of the article, provided the original work is cited. 
tion, we will at first review such debates, then develop a framework to analyse the degree or level of formality of movement organisations and its relevance in explaining ENGOs' reliance on personal networks.

The resource mobilisation theory suggests that the formality and institutional level of social movement organisations determine how they perform within the social movement. Their internal organisation and structure is directly related to the strategic and tactical manoeuvres of SMOs (Staggenborg 1988). Thus, SMOs with a formalised structure tend to adopt more institutionalised tactics and work through organisational networks, while those with less formalised structures will be more likely to rely on individual and personal networks. Furthermore, it is believed that informal SMOs have a tendency to develop a formal organisational form in the maturation process of the movement (cf. McCarthy \& Zald 1973, 1977; Gamson 1975: 91).

However, according to the new social movement theory, the organisational structures of new social movements are said to consist of 'diversified and autonomous units' (Melucci 1996), forming a fluid structure where borders and morphology of movement organisations constantly change (Diani 1990). Different from conventional social movements in which organisations are characterised by hierarchy and centralisation, the protest groups of the new social movements are characterised by decentralised networks of groups with direct participation of people involved.

These conclusions are based on research on social movements in Western democracies and do not necessarily hold for China - a country that has its specific cultural and political system. A decisive factor in this regard is the 'semi-authoritarian' political context in which movement dynamics takes place in China. The semiauthoritarian political constellation features formal state limitations on the freedom of association and speech, but at the same time also offers increasing social spaces for civic and voluntary action (Ho \& Edmonds 2008). Against this backdrop, it is necessary to distinguish the level of formality of SMOs. There are three aspects that characterise the level of formalisation and institutionalisation of SMOs, namely, the membership system, the internal institutions and the mechanism for decisionmaking. With these characteristics, SMOs can be placed on a continuum, ranging between formal and informal organisations (Table 1).

Firstly, the membership system relates to the degree of collective identity among those associated with a SMO. In informal SMOs, the constituency is often not clearly spe- cified, which is indicated by a poorly-established membership system. In contrast, a well-established membership system will boost a sense of belonging among members, and increase the common identity of the organisation.

Secondly, the internal institutional system-the rules and norms that govern the internal organisation-are not properly established and articulated in informal social organisations. A social organisation is a system that coordinates people's behaviour by means of rules and norms (Katz \& Kahn 1966), which direct attitudes and behaviour of an individual belonging to that organisation.

Thirdly, in informal social movement organisations, a mechanism for internal decision-making is often absent or poorly defined and formalised. Consequently, individual members will have little power in deciding organisational profiles, priorities and strategies. In formal social movements these internal decision-making processes are clearly structured and formalised, providing clear points of access for members in decision-making processes.

\section{SOCIAL CONTEXT OF THE CHINESE ENVIRONMENTAL MOVEMENT}

While analysing the emerging environmental movement in China, we will have to interpret it against the specific social context of the Chinese society. As noted by Diani and Donati (1999), the structure of environmental organisations and the environmental movement is not similar in every society. It is related to two specific dimensions in which such movements emerge and function: the political conditions of movement activism and the cultural context of China.

\section{Political Conditions of Movement Activism}

The development of the Chinese environmental movement and green activism is closely related to and structured by the specific political environment in China and has exhibited its own characteristics. Though the idea of democracy as multitudes of citizens taking to the streets may be attractive, it is as Ho and Edmonds maintain: 'simultaneously misleading as it disregards the nature of political change taking place in China today: a gradual shift towards a polity adapted to a pluralist society' (Ho \& Edmonds 2008: 10).

In general, the Chinese authorities are not keen on encouraging organised efforts from the public, which is often associated with political dissent. The state has established restrictive administrative procedures to govern

Table 1

Formal and informal organisations

\begin{tabular}{|l|l|l|l|}
\hline & \multicolumn{1}{|c|}{ Membership system } & \multicolumn{1}{|c|}{ Institutional system } & \multicolumn{1}{|c|}{ Mechanism of decision-making } \\
\hline Formal organisation & Well-established & Clear and articulated rules and norms & Well-established \\
\hline Informal organisation & Poorly-established or does not exist & Poorly-established or does not exist & Absent or poorly formalised \\
\hline
\end{tabular}


NGOs and is particularly strict in the registration of voluntary organisations. A dual supervising mechanism is utilised to control the growth of voluntary groups and organisations, which requires each NGO to find an organisation as its 'mother-in-law institution'. The political authorities also regulate the areas of activities in which voluntary organisations or NGOs may work in.

The state plays a monopoly role in Chinese ecological governance. Since the mid-1990s, aiming at complementing weaknesses of its administrative system, the central government established dozens of environmental government-organised NGOs (GONGOs), which have been playing an increasingly important role in China's environmental protection ${ }^{1}$. They responded to the internalisation of environmental protection, obtained international assistance and benefited from international expertise (Wu 2002).

Contradictorily, the restrictive 'semi-authoritarian' context was also conducive to green activism that can be seen from the rapid growth in ENGOs over the past years. By establishing informal organisations-façade institutions or 'companies'-ENGOs were capable of circumventing the stringent regulations for NGO registration. In addition, green activists made avid use of informal networking with Party and state officials. Through a web of informal ties, social structures were developed that were capable of effectively mobilising resources, appealing to citizens' newly perceived or desired identities, and building up a modest level of counter expertise against state dominated information on social cleavages and problems-be it labour rights, gender issues, dam building or nuclear energy.

This contradictory duality-a semi-authoritarian setting that is restrictive and conducive at the same timeforms the essence of what Ho and Edmonds termed 'the embeddedness of Chinese social activism' (Ho \& Edmonds 2008). A striking illustration in this regard, is the way urban activists in Shanghai have used the state's environmental discourse to achieve their own aims. By relying on Chinese official legal discourse, activists rendered themselves less vulnerable to political attacks and criticism by the local government. Eventually, this strategy gained the activists a victory over local state organisations (Zhu \& Ho 2008).

\section{Cultural Context of China}

The second aspect that makes Chinese ENGOs different from 'Western' ENGOs is the specific Chinese cultural context, which frames and structures the development, organisation and operations of environmental groups.

The impact of cultural traditions can be witnessed by the significance that informal rules, ethics and customs have in structuring social practices and institutions in China. The authority, norms and rules of the traditional Chinese state were prescribed by the principles of Confu- cianism (Duara 1995), and thus differed from the Western societies, in which individuals are bound by laws and legal institutions with different religious inspirations (Landes 1998; Metzger 2001). In China, individual ties and relations are prevalent. They are often referred to as the practice of guanxi, a special phenomenon of Chinese society. Guanxi, loosely translated as 'connections', is a specific Chinese idiom for characterising social networks in China, integrally linked to other building blocks of Chinese sociality, such as ganqing (sentiment), renqing (human feelings) and mianzi (face) (Gold et al. 2002).

It is suggested that guanxi function as a mechanism for coping with the absence of a formal and reliable system of laws and regulations (Yang 1994; Guthrie 1998; Xia 2000; Gold et al. 2002). For example, in the hierarchical one-party political system, individual networks are an essential element in successfully accessing the government, while at the same time it preserves the strength of the hierarchy and elitism of the political system (Guthrie 1998; $\mathrm{Xia}$ 2000). In the economic realm, industries construct, maintain and utilise 'guanxi' frequently. Where market economic incentives and rules are often unclear, 'private' economic actors tend to rely on guanxi and a gift economy to organise the necessary resources to keep their business going (Guthrie 1998).

\section{FUNCTIONS OF SOCIAL NETWORKS IN THE CHINESE ENVIRONMENTAL MOVEMENT}

Thus, both the young character of the movement and the specific political and cultural context of China frame the development of environmental activism. Seeing that all sectors in Chinese society are penetrated by these personal networks, it is no surprise that the complex of personal connections or 'guanxi' can be essential in environmental activism. In addition, pre-existing personal ties from previous social movements and collective actions are often well preserved, for example, those from the 1989's student movement at Tiananmen Square. It is, therefore, very relevant that environmental activism rely on personal networks to produce social leverage.

In an environmental movement, personal networks function primarily in two specific ways. Firstly, with the characteristics of Chinese political institutions, personal ties are used in accessing the political system. Secondly, personal networks promote the establishment of coordinated actions.

\section{Accessing China's Political System}

Interactions with the political system constitute one important aspect of using personal networks in China's environmental movement. As governments at different levels are merely monopoly actors in environmental governance, environmental activists have to interact with Chinese political authorities if they want to influence en- 
vironmental governance. Their interaction with governmental and political authorities focuses on two aspects: mobilising political protection and generating influence on the government's policy agenda.

Firstly, personal networks are used to acquire political protection from the current political system. The legal framework on NGOs is at present weak; the ENGOs as representatives of the public have to acquire a certain level of protection and recognition from governmental agencies, before they can produce social leverage. Informal interactions and personal networks play an important role in gaining and safeguarding such protection.

Secondly, personal networks are used to generate power and influence, and participate in policy-making processes. Environmental issues are not a major priority for the Chinese government. Through individual networks with key officials in the government, ENGOs have a better chance of influencing the political agenda, and being acknowledged by the government as participants in the discussion of policy processes. In this way, interest articulation in the political arena is possible without access to formalised channels.

\section{Promoting Coordinated Actions}

Experiences in many developing countries have shown that networks play a crucial role in strengthening the capacity of ENGOs, where the latter are weak in resources and capabilities. Networks substantially facilitate communication with other constituencies inside and outside the environmental movement, and also within and beyond a locality (Royo 2000). The loosely structured forms of networks can link both large and small organisations efficiently, and help local NGOs to grow and develop. In this way, personal networks can be important in promoting collaboration between ENGOs and a variety of other actors.

Chinese personal networks also allow interest exchange between private and public affairs (Hwang 1987). In Western societies, contracts, laws and institutions govern conflicts between private and public interests (Yum 1988). In China, with many of these institutions, contracts and laws still in the making, individuals and social movements use the practice of guanxi and personal connections to mix private with public affairs (Wang 1987; Yum 1988).

\section{METHODOLOGY}

In this article, the cases of Xiangfan (in Hubei province) and Shanghai are analysed to examine the dynamics of Chinese environmental movements (Figure 1). Each case investigates the environmental networks comprising ENGOs and their communities. From these networks, subcases are selected, consisting of an ENGO or a personal network of activists. Before analysing the cases, we will briefly reflect on the diversity of the case studies, by reviewing the relevant contextual aspects of each case.

Xiangfan, a poor metropolis with a relatively long history compared to other Chinese cities, has developed under the influence of Confucian traditions and conventions. Although in transition, the city still witnesses a strong reliance on a planned economy in its economic growth model, much more than other Chinese cities of comparable size. Located in middle China, this city sees relatively slow economic development, in comparison to those along the east coast. Its political system is relatively constrained and seems to be not very efficient in promoting an economic transition to establish a well functioning market economy locally. Influenced by local culture, citizens highly value families and personal connections. Building personal relationships and practically using them in economic and political engagements are very prevalent in Xiangfan. In the growth of green activism, personal networks are essential in mobilising common identities and organising collective actions.

Shanghai is the second largest metropolitan city in China and has experienced rapid economic development. It is a model for the east coast cities that have all developed prosperously and have witnessed a quick transformation towards a market oriented growth model. Shanghai has been an important city in Chinese contemporary history. As a port city it represents a mixture of both Chinese and Western cultural values. Its political and economic systems rely less strongly on personal networks than the other Chinese cities. The local culture equally witnesses less strong interpersonal relationships. Its political system is strongly repressive to citizens' political articulation, which distinguishes this metropolis clearly from other major Chinese cities.

Together these two cities reflect environmental activism in two typical cities from middle China and the coast. Looking at the location of ENGOs, they seem to develop only in several focused regions across China. According

Figure 1

Green Hans River's internal organisation for decision-making

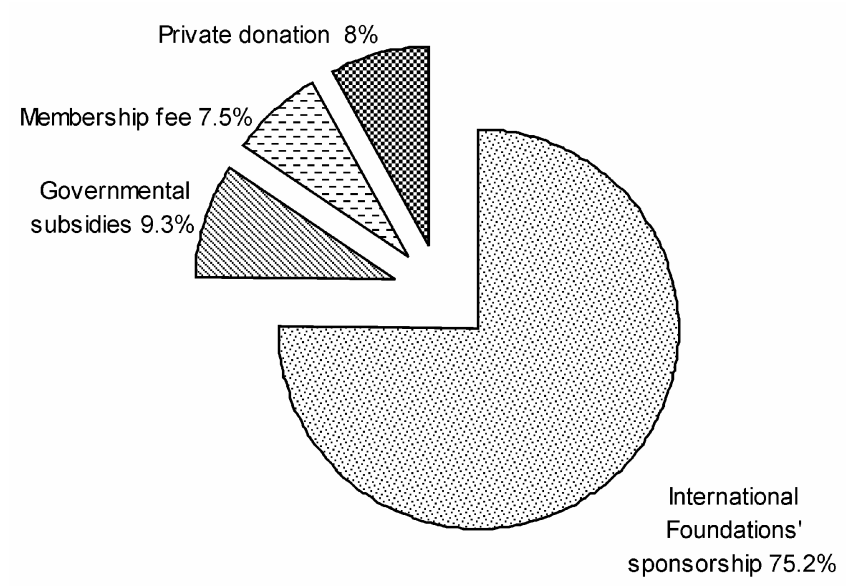


to the survey conducted by the All-China Environmental Foundation, currently, ENGOs develop mainly in four areas: Beijing and Tianjin in the north, Shanghai in the east, the southwest area of the Sichuan and Yunnan provinces, and Hunan and Hubei in the middle provinces where ecological resources are relatively rich (ACEF 2006). Thus, these two cases cover the major locations where southeast ENGOs are active.

But we should also recognise that important loadings of these contextual factors are not included in our selection of case studies. The two cities were of considerable size (>1,000,000 inhabitants) leaving the more rural developments in towns and villages out of our analysis (which might affect the relevance of personal networks and of the degree of repressiveness of political systems). Further, the types of ENGOs that are found are primarily those committed to environmental education (which might not cover all possible strategies that Chinese environmental organisations adopt).

\section{THE CASE STUDIES OF XIANGFAN AND SHANGHAI}

\section{Environmental Activism in Xiangfan}

Regulations by the restrictive Chinese law allow only one organisation of any one type to register at each administrative level; the Green Han River (GH), a grassroots ENGO founded in 2002, appears to be the only independent registered environmental group among the very few ENGOs that exist in Xiangfan ${ }^{2}$. Its goal is to raise the public's environmental awareness, and the main area of activity is environmental education. Although the GH has 122 individual and forty-one collective members ${ }^{3}$, it strongly relies on its three full-time staff.

Since its establishment, the GH has been autonomous from the city government, mostly because it does not rely on government subsidies, like most of the local social organisations do. Its income is mainly composed of aid from international foundations, government subsidies (which form a small part), and membership fees. Financial support from international organisations accounts for the majority of its income since its establishment in 2002 (Figure 2). The major international sponsors are the Ford Foundation, the Global Grant Foundation, the Canada Civil Society Fund and the World Bank. A small amount of income also came from the government to subsidise particular projects, in which government actors participated.

In order to be effective in organising an environmental movement, the GH has also set up relatively formal institutions. Decision-making mechanisms are built according to the nature of the tasks (Figure 3). Three levels of meetings are held, namely the president's meeting, the council's meeting and the members' meeting. Authority and frequency of these three meetings differ, with the president's meeting being organised most often and composes of a small circle of top officials. A democratic system exists for selecting leaders - the president and vicepresident are selected from councilors, and councillors are elected by members of the GH during the members' meeting, which is held every 4 years. This system follows a democratic procedure and is effective in making members realise their rights of management in the GH (Interview with Mr. Sun, member of the council's meeting, 14 September 2005).

However, the mechanism to maintain members is through connections, mainly composed of Ms. Yun's personal networks. The leader of the GH, Ms. Yun, has a relatively broad personal network that is composed of local civil servants and members of the Xiangfan City People's Political Consultative Conference (XCPPCC) and the Xiangfan City People's Congress (XCPC) (Table 2). These connections, partly through her work and partly through a shared residential area that form her personal network, account for a major proportion of the total number of members.

Through her work, Ms. Yun has gained a rich experience in local politics. She worked for 20 years at the Office of Overseas Chinese Affairs in the Xiangfan gov-

Figure 2

Composition of the Green Han River's total income (2002-2005)

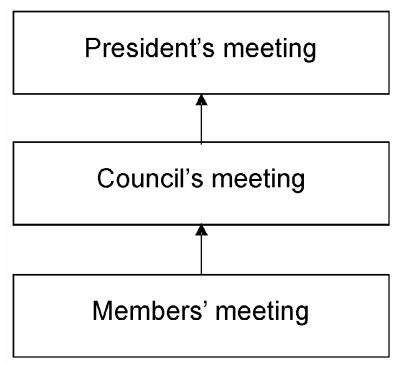

Figure 3 Location of Xiangfan and Shanghai

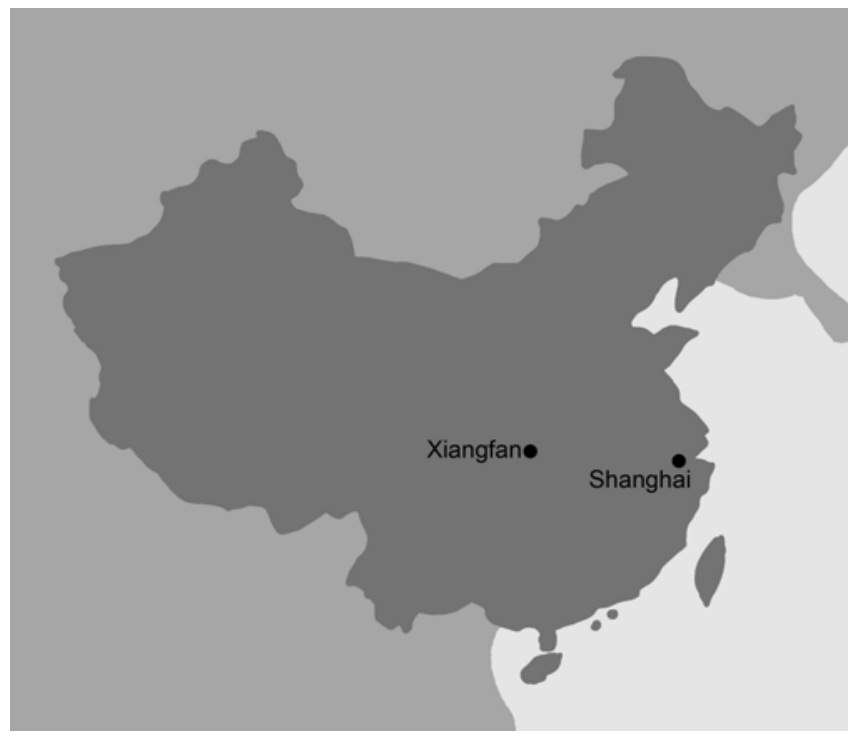


Table 2

Occupation of Green Han River's members (total members=122)

\begin{tabular}{|l|l|}
\hline Occupation & $\%$ \\
\hline School teachers & 14.7 \\
\hline Journalists & 13.4 \\
\hline Governmental units & 39.1 \\
\hline XCPPCC and XCPC & 13.1 \\
\hline Companies & 13.1 \\
\hline Others & 6.6 \\
\hline Total & 100 \\
\hline
\end{tabular}

ernment before she retired. Furthermore, she was a member of the XCPC and the XCPPCC, serving in each for one term ${ }^{5}$. Ms. Yun developed close relations with her colleagues and co-members in the XCPC and the XCPPCC. Additionally, Ms. Yun lives in the same area where the compounds of the XCPPCC and the XCPC are located. Both these institutions are danwei that provide housing for its employees ${ }^{6}$. Thus, Ms. Yun developed close ties with governmental individuals, whose homes were in the same residential area as well. In all, these two factors enabled Ms. Yun to build personal connections with civil servants and members from the XCPPCC and the XCPC. Ms. Yun's network was maintained in an informal way and continued to exist even after she retired. Furthermore the longer they are maintained, the stronger the personal relations can become, because the personal ties that are developed bring a sense of familiarity and connection to the counterparts.

\section{Campaign Initiating Environmental Education}

To demonstrate the roles of grassroots activists' efforts in promoting Xiangfan's environmental reform, a campaign led by the $\mathrm{GH}$ is presented, showing the tactics used to articulate and demand environmental reform-in this case the initiation of environmental education. The GH successfully achieved its goal by organising coordinated actions with the Friends of Nature (FON) and two government agencies, the city Environmental Protection Bureau (EPB) and the Bureau of Education. As a result of this effort, environmental education was institutionalised in the local educational system.

In order to initiate environmental reform of education, the GH had to build organisational linkages to access resources and mobilise coordinated actions. "We need all kinds of resources, no matter non-material resources or material ones”, as remarked by Ms. Yun (Interview with Ms. Yun, president of the GH, 19 December 2003). A dynamic and strategic use of personal networks is recognised in the interactions between the $\mathrm{GH}$ and other actors. Besides, organisational networks were also built with a small number of collective actors.

The GH acted as an important structural linkage coordinating various actors. Under Ms. Yun's efforts, coop- eration was reached among three organisations, the EPB, the Bureau of Education and the GH. Through these linkages with government units, the GH acquired some support for transportation and small financial donations. As for the two governmental agencies, environmental education was of importance; by sponsoring this joint programme, both government organisations could achieve political credits. In the process of initiating such cooperation, the role that Ms. Yun played was critical. Having had connections with both the EPB and the head of the Bureau of Education, Mr. Yun bridged the gap between the EPB and the Bureau of Education with little difficulties.

In the implementation of public education, the World Bank covered most of the expenses. The GH, as the main actor in the programme, completed the majority of the work: it invited professionals from the FON, designed the education programmes, organised participants, arranged venues and so on (Interview with Ms. Ye, vice-president of the GH, 6 September 2005). For the GH, the most essential resource needed for the implementation of the educational programme was authority, issued by the government. Under Ms. Yun's design, in the process of organising this programme, the Bureau of Education and the EPB jointly promulgated a document titled the 'Notification to launch environmental education in middle school, primary school and kindergartens'. Through this document, the GH could smoothly mobilise participants. Talking about the issued document, Ms Yun remarked: "[I]t is a powerful sword for us...[We have] no need to worry about getting participants"'(Interview with Ms. Yun, president of the GH, 18 December 2003). When conducting the training course, political leaders of the two government agencies participated in important events such as the opening ceremony and 'graduation day'. They gave speeches, distributed certificates to participants and thus brought authority to the programme.

This programme was a success. Five hundred teachers who came either from the city or rural areas were trained. Lectures were organised in eighty schools from 2002 to April $2005^{7}$. A large number of students and young children were imparted environmental education, through which their environmental awareness was raised. The environmental programme was also institutionalised in the local educational system. Schools are now required to include environmental courses and thus receive lectures provided by the GH. Later, this programme was established as a citizen's educational programme by the Spiritual and Civilization Construction Office, as an experiment that was started by four residential communities and which was to be broadened later on to include the whole city. The four communities were Wangfukou, Tanxicun, Shuixingtai and Gaozhuang that are all located in urban areas. In this way, the GH could widely lecture on environmental protection, and also teach the public how to protect itself when its rights were affected by environmental pollution. 
The success of the $\mathrm{GH}$ in initiating and implementing this educational programme is based to a significant extent on the GH's strategy to initiate coordinated actions with government authorities. In the context of Xiangfan, this seems very necessary for launching NGO's projects. By utilising its personal network, the GH acted as a broker, building structural linkages and institutionalising environmental issues in policies.

In this case, personal networks appeared to be an effective mechanism utilised to mobilise environmental improvements. The ENGO, due to the social elite who have personal ties with officials, played a key role in the environmental reform processes. Personal involvement appeared to be a crucial strategy to facilitate communication and coordination among the movement actors.

\section{Environmental Activism in Shanghai}

\section{Review of Shanghai's Environmental Community}

The emergence of environmental activism in Shanghai appears to be relatively late for a cosmopolitan city of its size and development. Shanghai's NGOs have only begun to launch environmental projects since 2000, when it became fashionable to contribute to activities to improve the environment [Interviews with Ms. Shao, programme officer of the grassroots community, 11 January 2005, and Mr. Qian, previous participant of the Shanghai Green Student Forum (SGSF), 13 January 2005]. The growing environmental activism in this cosmopolitan city was strongly deterred by restrictions applied to environmental organisations, mostly related to the registration of such groups $^{8}$. Illegal groups can hardly survive in the local political environment (Interview with Ms. Fang, core member of the grassroots community, 25 January 2005). A small number of ENGOs exist in Shanghai solely because they are not confrontational to the government. Similar to groups in other places across the country, Shanghai's ENGOs lack a professional knowledge base (Lee 2003, 2007).

In Shanghai, three types of groups can be identified: GONGOs, international NGOs (INGO) and grassroots voluntary organisations. Shanghai's GONGOs are active in complementing government agencies within their responsibilities. Several of them play a strong role in Shanghai's environmental protection, and can be divided into three kinds: a) traditional mass organisations, such as the Youth League ${ }^{9}$, that act as bonds to link the grassroots NGOs with environmental agencies, and channel public participation into this process; b) organisations that are affiliated with environmental protection agencies, such as the Shanghai Environmental Educational Committee that conducts environmental education and is also in charge of mass campaigns and environmental educational projects of the Shanghai Environmental Protection Bureau; and c) professional organisations that promote environmental protection in specific fields of activities, such as the Shanghai Wild Animal Protection Association (SWAPA) that acts as a professional association dedicated to the protection of animals. GONGOs initiate and implement their activities strongly depending on the administrative structure. Owing to the effective bureaucratic system of the municipal government, Shanghai's GONGOs are capable of playing a prominent role amongst the various environmental organisations in the city.

The second types of environmental group in Shanghai are the INGOs. They work mostly on issues of nature conservation. With a largely undeveloped green civil society in Shanghai, very few international ENGOs exist, and even fewer conduct projects in the city. A majority of international groups have their projects outside Shanghai, and use the city as a base. An example of these groups is the Wildlife Conservation Society (WCS $)^{10}$. Shanghai's INGOs work closely with international companies, particularly in providing environmental education to the public $^{11}$. Unlike Beijing's INGOs, they are less involved in mobilising local environmentalism. Recently, the Shanghai Oasis (SO), a local grassroots group, was established with the support of the WCS, as a part of its growing scale of activities. Also, the success of this facilitation can be attributed to the fact that the work of the SO is 'politically innocent'.

Currently, only a limited number of grassroots groups are specifically dedicated to environmental protection activities. Though their focuses are different, a general sense of environmental activism is gradually being formed amongst grassroots NGOs. Grassroots NGOs committed to environmental protection are mostly registered organisations that can be distinguished into three kinds: social associations, non-profit enterprises and student environmental groups. At the same time, a small number of them are not registered and some are Internetbased.

In general, Shanghai's grassroots NGOs have difficulties in getting a legalised status. Because of the restrictive regulation of the municipal government, very few membership- based NGOs are allowed to exist. So, they are often registered as non-profit enterprises. And very few social organisations specifically devote themselves to environmental protection. Most of the ENGOs cover a variety of goals in addition to green activism; they are religious associations and NGOs that provide social services. Currently, the number of ENGOs-primarily composed of social associations and non-profit enterprisesaccount for a very small proportion of the total number of NGOs in Shanghai; numbers of these two types of NGOs are also not available.

Apart from these types of NGOs, student environmental protection associations are another type of grassroots groups that were established in universities. The emergence of these groups was a result of growing environmental concerns among students. The groups function 
as a means for young people to articulate their common interests towards nature protection and environmental education. Currently, several dozens of student environmental protection associations exist. The SGSF was formed especially to build coalitions between them.

Besides registered ENGOs, web-based environmental groups are an important type of unregistered NGOs in Shanghai. This type of ENGO is organised among individual citizens who share common interests, such as travelling, protecting animals and conducting social charity activities. Green activism is a growing interest among individual citizens in Shanghai. In recent years, the cosmopolitan city has experienced a boom in various kinds of online groups, through the intense usage of the Internet. These groups consist of individuals who share interests in, amongst other things, cars, pets and travelling. The number of participants in this kind of web-based NGOs is large ${ }^{12}$. They are characterised by a weak organisation and a strong reliance on computer-based communication (CBC). This type of a group is formed informally by individual volunteers. Because of the difficulty in finding a supervising institution, very few of them get registered, and most of these groups thus remain loosely organised.

\section{Case Study of the World Wide Fund for Nature, Shanghai}

As grassroots NGOs are the main focus of this study, the World Wide Fund for Nature (WWF) Shanghai has been selected because it represents a successful organisation in the local environmental community, it has a significant number of members and a longer history. Originally established by the WWF International, the WWF Shanghai was one of the online forums of this organisation that started around $2000^{13}$. Like the WWF's web pages in other cities, the WWF Shanghai's website receives a loose supervision from the WWF China's general office in Beijing, mainly on affairs related to the Internet site. Very little formal linkage exists between the group of environmentalists in Shanghai and the Beijing office. However, a number of local residents became members of WWF Shanghai's digital forum and developed face-toface interactions. In 2005, the WWF Shanghai had 1000 members, although the core participants that logged onto its website numbered only several dozens ${ }^{14}$. What is specific to the informal relationship formed among the WWF Shanghai's members was their low level of internal organisation.

Unlike other voluntary groups, CBC was the main mode of communication. To each insider, the virtual space created by the Internet appears as another world, which provides a platform for communication. Through the Internet, environmental concerns were discussed and knowledge and information about watching birds were exchanged. What is more, offline activities were organised, which further led to the development of friendships and intimate personal relationships among them. With face-to-face networks being formed, the network built through virtual communications was consolidated. The instrumental use of new technology in building personal contacts implied that levels of trust among these individual citizens in Shanghai were relatively high. This method became an alternative for individuals to realise their right to freely express themselves under Shanghai's restrictive political censorship ${ }^{15}$. The activists felt more secure and there was a greater secrecy in organising collective actions ${ }^{16}$.

In the WWF Shanghai a very low level of internal organisation exists. No individuals act as leaders. Several figures that participated in the group longer than other members were active in initiating activities and projects. Yet, because this group had no legalised status, its members did not find it necessary to become further organised. Individual members were equal, with their voluntary will as the primary principle directing informal management.

However, the informal status of the WWF Shanghai affected its organisational development. In particular, building organisational linkages was not very successful. The illegal status of the WWF Shanghai prevented activists from developing organisational linkages with other actors, such as GONGOs, ENGOs and scientific experts. Only a few scientists who had sympathy for the informal group were contacted. For instance, professors from the biology department of the East China Normal University and the Shanghai Normal University were contacted often (Interview with Mr. Zhao, core member of the WWF Shanghai, 14 April 2005). In addition, only personal networks were formed between active members of the WWF Shanghai, individual media staff and scientists. Such interactions functioned as linkages between the volunteers and a small number of university professors of ornithology. Yet, because such relationships are informal and flexible, only limited cooperation was facilitated between the WWF Shanghai and the academic scholars they contacted. The WWF Shanghai's illegal status prevented acceptance by other institutions and actors, who feared the troubles that may come along as a result of contacts with this unregistered mass group. In other words, registration and formalisation of the WWF Shanghai was greatly needed for its further development.

Under such conditions, around 2005, the core members formed a new voluntary group, called the Shanghai Wild Birds Protection Association (SWBPA). After a year, it was registered as a secondary social organisation under the supervision of the other GONGO-the SWAPA ${ }^{17}$. With a legalised identity, the SWBPA participated in activities oriented at protection of birds, together with professional organisations from the government and universities. It began to collaborate with Shanghai's governmental agencies in various kinds of bird investigations.

The establishment of the SWBPA represented the development of another grassroot ENGO in Shanghai. Internal institutionalisation is very important for a group, 
not only for the group's survival, but also to gain social influence and build organisational collaboration and networks. Informal structures prevented the WWF Shanghai from being recognised by other organisations, and thus constrained the formation of organisational development in the long term.

\section{Environmental Campaign in Shanghai}

Built in 1922, Jiangwan Airport was the first military airport in China. After being deserted for decades, this area turned into a marshland covering more than $8 \mathrm{sq} \mathrm{km}$, and accounted for more than 1 per cent of the land area of the entire city. Because of its rich water resources and the lack of human disturbance, the area evolved into a complete ecological network and a heaven for wildlife. Since 1997, the Shanghai municipal government has been planning to develop it into a high-class sub-city centre in the northeast of the city ${ }^{18}$.

Yet, this project was only acknowledged to the public at the end of 2001, when construction of the New Jiangwan Town began. During the formation of this policy, no Environment Impact Assessment was conducted, and neither was the public consulted for their opinion on this policy. Under such circumstances, environmental activists began to protest against the marshland's destruction (Interview with $\mathrm{Mr}$. $\mathrm{Li}$, core environmental activist of this campaign, 8 January 2005). A campaign by environmentalists from the WWF Shanghai was developed, which can be divided in two stages. In the first stage, the group acted mainly as a leader, while the second stage marked a decline in its impact.

The WWF Shanghai was the main actor that coordinated the campaign against Jiangwan Town construction. It organised a limited number of events, which illustrated its central role among actors in this campaign.

In the initial stage, environmentalists faced difficulties in effectively mobilising resources they needed. Prevented by its informal organisation and illegal status, the WWF Shanghai could hardly build a professional scientific team for exploring the value of the marshland. Although investigations on the Jiangwan marshland were organised using 200 of WWF Shanghai's members, interested citizens and a small number of academic scholars, no concrete scientific report was put together to prove the biological and ecological value of the marshland.

In addition, what also weakened the environmentalist force was that very few social groups joined this campaign, mainly because of the issue's political sensitiveness. For ENGOs that the WWF Shanghai had links with, such as the Grassroots Community (a local ENGO) and students' groups, opposing the government on this issue meant serious risks to their status. As a consequence, no integrated alliance could be organised in this campaign. Only environmental activists in web-based groups, such as the Shanghai Nomad Club (a travelling group) and the
Common Wealth Management Project (an online group committed to providing education and services) were mobilised to join the investigation and sign the petition ${ }^{19}$. Such linkages were built through personal networks among the common members that the WWF and several web-based groups had (Interview with Mr. Zhao, core member of the WWF Shanghai, 11 May 2005). Yet, because of the loose organisation of both the counterparts, limited collective efforts were made.

Lacking experience and careful planning, building public opinion constituted the primary strategy that environmentalists utilised to attract political recognition through the campaign. It was mainly organised through the conventional mass media and the Internet, and local journalists were contacted. Yet, under pressure from the Yangpu district government, only a limited number of preliminary news reports were completed and published on the marshland ${ }^{20}$. Soon, further reports on this issue were banned. CBC then remained as the only tool for releasing news and constructing public consensus. Such a strategy was still quite influential among the public that had access to the Internet. Information on the destruction of the marshland was distributed to a number of online forums of web-based groups, including the Shanghai Nomad Club and the Common Wealth Management Project. In addition, a special website dedicated to the marshland's protection, named 'The event of Jiangwan', was developed, on which comprehensive information and pictures were placed. In order to increase the number of readers, this website was also linked to the official website of the Shanghai Municipal People's Congress (SMPC) that was holding a conference in 2002. In a week's time, the visitors to this site reached 3000 and the number continued to grow. Though the government blocked this site after a month, it was efficient in spreading the news up till that moment. In early 2002, through interaction on the Internet, public opinion towards protecting Jiangwan, as the last marshland of Shanghai was influenced.

Later on, meetings were organised among environmentalists to further disseminate information on this issue. In order to broaden the campaign's influence, botanists, ecologists, ornithologists and environmental scientists were contacted and invited to participate in meetings ${ }^{21}$. A meeting at the Huadong Normal University was held, with around 70-80 people, including scholars, experts and activists from the WWF Shanghai. On this occasion, the values of the Jiangwan marshland were discussed, which led to the signing of both off- and online versions of a petition. As a result, 1000-1500 signatures were collected. Since several scholars served as members of the SPMC, this petition was inserted into the formal policy process, by submitting it to the $10^{\text {th }}$ SPMC of Shanghai in 2002. There it was suggested that the Municipal Construction Department should reconsider the original plan of city construction, and to establish a nature reserve around the Jiangwan marshland area $^{22}$. 
Following the SPMC meeting, the municipal government halted the construction. The Shanghai Construction Commission was ordered to reinvestigate this issue. For the first time, the public, led by activists, scholars and political representatives successfully influenced local government policy. Although the district government took strong measures to repress publications in the mass media about the campaign, the scientific support appeared to be an important resource that effected local policy. And it demonstrates that the public could influence this process through institutionalised policy channels.

Starting in late 2002, the Yangpu district government, supported by the City Planning and Construction Bureau of the municipal government, adopted repressive actions to weaken the coalition of environmentalists and scientists. The collaboration between the WWF Shanghai and its partners in the movement was counteracted through interventions of political authorities. In addition, governmental agencies took the chance to initiate a green washing of the project through its control of the majority of mass media in Shanghai. As a result, a revised construction plan was brought out, and only an area of around $200 \mathrm{sq} \mathrm{m}$ of the marshland was preserved (Interview with $\mathrm{Mr}$. Li, core environmental activist of this campaign, 8 January 2005).

With the short duration of protest and limited revision of the original plan, we can conclude that the social leverage of this campaign was very limited. Nevertheless, individual activists articulated their opinions through collective efforts, and expressed their demands for transparent policy-making. In the enclosed political atmosphere of Shanghai, this is one of the few cases where environmental policy was influenced by civil society groups.

\section{COMPARISON OF ENVIRONMENTAL ACTIVISM IN URBAN CHINA}

As illustrated by the cases, the Chinese public, for the first time is represented in the local environmental governance, their voices articulated and policy-making affected. In this section, we will compare organisational development and strategies of ENGOs and discuss the use of personal networks as movement strategies in varying social contexts.

\section{Formalisation Level of the Environmental Movement}

Despite the repressive environment in the two case studies, growing green activism can be recognised in both Xiangfan and Shanghai. Regarding internal organisational development, both cases illuminate that Chinese ENGOs are less than 10 years old and yet to develop into professionalised organisations. As to the strategic adoption, being young organisations makes Chinese ENGOs have the specific characteristics of all young or embryonic NGOs, among which is a stronger reliance on per- sonal networks. This aspect is especially evident in Xiangfan. As shaped by the city's past, the reliance on guanxi is rather strong. It appears that the adoption of informal mechanisms can hardly be replaced by formal interactions of organisational networks, and this continues to be the case. In comparison, Shanghai's ENGOs show little sign that close personal contacts are crucial movement strategies to adopt. The specific social circumstances have not led to a strong reliance on and utilisation of personal linkages.

\section{Adoption of Personal Networks}

Although the phenomenon of using guanxi networks is widely recognised in the Chinese green activism, the two case studies illustrate interesting differences in the utilisation of these personal networks in Chinese ENGOs. In Xiangfan, personal networks proved to be important in the development of the $\mathrm{GH}$ and the initiation of its activities. Consequently, it was found that the dependency of this organisation on the personal relationships of its leader makes it very vulnerable. However, relatively weak use of personal networks was recognised in the case of Shanghai. In Shanghai, personal networks were developed through common membership of NGOs without one member acting as a clear leader. A small number of common members acted as linkages bridging different ENGOs. Because the identity of these individuals together defined the profile of the organisation they belonged to, the personal linkages that were formed also bear organisational characteristics. The Shanghai NGOs were less likely to be formed through or draw upon personal relationships.

As to the functions of personal networks in environmental activism, the case of Xiangfan illustrates that personal networks were used in two dimensions: 1) the interaction between ENGOs and the political authorities, through which political resources were garnered; and 2) personal networks used for linking various movement actors and forming coordinated actions.

First, by using personal networks, the GH was able to acquire political protection and assistance from authorities of various kinds. The ENGOs, as representatives of the public, have to gain access to authority and protection by governmental agencies before they could produce social leverage. This often starts early in the phase of registering NGOs, and continues when ENGOs carry out various environmental protection activities through which they criticize current (economic, political or societal) developments. Linked through personal ties, political officials could endow key figures of ENGOs with certain resources, authority, legitimation and protection in carrying out these activities. Such interaction generally is conducted based on face-to-face contact, personal trust and exchanges of mutual advantages, and could hardly be replaced by organisational networks. 
Second, personal networks are functional in forming coordinated actions. In Xiangfan, Chinese ENGOs activated personal networks in linking with other sectors in society to build pressure, organise activities and develop consensus in support of their ideas and goals. Through using the personal networks of leading figures of ENGOs, movement actors are not constrained by organisational boundaries. It is difficult to see how in these situations personal networks could be replaced by organisational networks. This distinguishes Chinese environmentalism from its Western counterparts, where institutionalised mechanism and organisational networks are crucial elements of coordinated actions, rather than personal networks. Chinese environmentalists manage to generate a certain social leverage through their coordinated actions and activities, and personal networks usually play a significant role in this.

Under the coercive political atmosphere of Shanghai, very little space was available for organising collective campaigns. Although highly committed to this campaign, individual activists were too inexperienced to develop a successful protest against their repressive government. Personal networks were rarely used in movement dynamics. Collaborating with the media and the scientists and relying on an institutionalised channel to affect policymaking were the primary strategies adopted in the campaign of Shanghai.

Media staff is a very important partner for the Chinese environmental movement. They prove to be active collaborators in building public consensus on the objectives and ideas of ENGOs. Whereas efforts of building public consensus through the media take a longer time, the social impact can also be powerful.

The reason that media representatives are an important partner in the contemporary Chinese environmental movement is related to two major developments. Throughout the last decade, the media has increasingly gained a growing independence from the Party-state. To some extent they had to become more economically independent as state subsidies diminished, while at the same time state control relaxed somewhat on those issues that were not of high political importance ${ }^{23}$. In this process, the public's growing environmental awareness could be strongly reflected through increased coverage on television, radio and in newspapers. Secondly, in recent years, the central government, particularly led by the State Environmental Protection Agency (SEPA) ${ }^{24}$, has begun to strengthen environmental education at the local level. Larger numbers of news reports and programmes are re- quired to educate citizens on environmental protection, in order to realise the central government's policy. This has provided more possibilities for environmental media reporting at various levels and through different media.

Like in many other countries, scientists composed another strategic partner for the Chinese environmental movement. Many personal networks of leading environmental activists included scientists. As argued by Cao and Suttmeier (2001), with the development of a market economy and the transition of the new political leaders, scientists and scholars began to be better supported by the ruling authority.

\section{DISCUSSION AND CONCLUSION}

The cases of Xiangfan and Shanghai illustrate that the Chinese environmental movement is still in its early stage, with ENGOs incompletely formalised and relying on personal networks (Table 3). Some indications are found in the establishment of formalised and professional NGOs in both cities. This indicates that the end stage of the dynamic development of Chinese ENGOs till this moment largely differs from their Western counterparts that are highly formalised organisations utilising organisational networks. In the case of Shanghai, direct transformation to this form is found. It is no accident that these ENGOs are strongly linked to and supported by international umbrella organisations that operate from the 'Organisation for Economic Co-operation and Development' countries in the West. In the case of Xiangfan, the path of development shows early signs of becoming institutionalised. Yet, the GH's organisational structure also shows that personal networks play a strong role internally, which are important in constructing and developing a civil society group. Intimate connections were utilised to exchange resources and power in organising this ENGO. As a consequence, the utilisation of individual ties is likely to continue for some time under the influence of the local culture and current political system.

Our case studies show that environmental activism in China may not be an activity with a fair degree of autonomy and self-regulation, but it occupies a social space that is enmeshed in a web of interpersonal relations and informal/formal rules between political and social actors. Yet, different from a situation in which activism is merely repressed, the Chinese embedding conditions both limit the development of environmental organisations, and also make it possible. These 'embedding ties' that can successfully cross the divides between the Party-state

Table 3

Organisational development from a dynamic view

\begin{tabular}{|l|l|l|}
\hline & GH, Xiangfan, Middle China & WWF, Shanghai, East coast of China \\
\hline History & Young (4 years) & Young (5 years) \\
\hline Formality levels & Medium & Low \\
\hline ENGOs' development & Signs of institutionalization & Institutionalised; utilising organisational network \\
\hline
\end{tabular}


and society have enabled the young environmentalists to play an increasingly critical role in the greening of the government (Ho \& Edmonds 2008). At the same time, 'the embedding ties' also bear local cultural features that influence the functioning of the environmental movement across the country. Located within a distinctive network society that sees prevalent use of personal networks in both political and economic spheres, the Chinese environmental movement can hardly be left unaffected. In this study, different degrees of reliance on personal networks in the two cities reflect dynamics of local cultural tradition and customs between the coastal metropolis of Shanghai and Xiangfan in middle China. From this perspective, we can conclude that the Chinese environmental movement is characterised by interactions and dynamics that vary at specific locations.

\section{Acknowledgements}

The authors would like to thank the two anonymous reviewers of this journal for their comments and suggestions. Special thanks also go to Xiaoyun $\mathrm{Li}$, Dean of the College of Humanities and Development, China Agricultural University for his continuous support that made this publication possible.

\section{Notes}

1. For instance, the China Environment Science Association (est 1979), the China Environment Protection Industry Association (est. 1993) and the China Environment Fund (est. 2002).

2. The reason that few registered environmental groups exist is also related to the Regulations on Social Organizations, promulgated in 1989.

3. Collective membership is one way of recruiting participants collectively. It is based on organisational linkages between the $\mathrm{GH}$, and local governmental organisations, schools and business institutions.

4. The XCPPCC is a political advisory body in China. Its members' term of office lasts 5 years. The GH's members include those who are serving as present members of the XCPPCC, but also retired members. The XCPC is the legislative institution in China. Its members are elected indirectly from the district level, and one term of office is 5 years.

5. Ms. Yun is an active actor in local politics. She participated in the mayoral elections in the year 2001. The mayor's term of office lasts 5 years. She had also been recommended as a member of the XCPPCC since 1984 for four rounds. She also served as a member in the permanent committee of the XCPPCC. This committee functions as an alternative organ of the XCPPCC in between meetings. It meets every 3 months to discuss major policies and social issues.

6. In China, danwei refers generally to a special mechanism under the centrally planned economy. It provides welfare and carries out government policies, ranging from family planning to public hygiene campaigns. Danwei also is a social institution that provides for employees' welfare benefits, such as health care, housing, day care and pension. It also works as a social and political control mechanism for the Chinese government. This phenomenon is becoming less apparent nowadays after the market economy developed. Yet, it is still prevalent in Xiangfan.

7. Refer to the GH website www.greenhj.org
8. It is very difficult for grassroots NGOs to find a supervising institution that is required by registration.

9. This is a government organised non-profit organisation that politically belongs to the Chinese Communist Party. The league is organised according to the party pattern. The Communist Youth League was also responsible for guiding the activities of the Young Pioneers (for children below the age of fourteen).

10. The WCS established an office in Shanghai in the late 1980s. It conducts education and research in protecting animal species.

11. For example, Shoots and Roots, an INGO committed to environmental education, cooperated with the local enterprises HP Inc. and Alcoa Inc. in its programme in 2005. In the same year, the WCS collaborated with L'Oreal (Shanghai) to initiate an educational programme for 'Concern on Yangtze, protect Chinese river dolphin.'

12. Statistics provided by the Shanghai Nomad Club-a web-based travelling group claims to have 15,200 registered members.

13. The WWF China is a branch of the WWF International. It entered China in the 1980s, and was the first international ENGO that worked in China. The WWF China works closely with the Chinese government. The WWF China provides virtual spaces for environmental activists in six cities, by cooperating with the website charged by Renmin Daily.

14. Registered individuals are regarded as members. Those who visit the website as regularly as two or three times a week are defined as core members. Only the core members represent the voluntary group well.

15. Because the Internet is controlled by the government, radical ideas are still regulated by the concerned political authorities. But free speeches can be made in anonymity.

16. A great number of individuals work in companies, where they are provided with computers, and thus are able to access the Internet when they are at work. University students, most of them who live on campus, can also easily access the Internet on campus.

17. As a second grade social organisation the SWBPA will not be able to possess an independent bank account without the permission of its supervising institution.

18. Yangpu district government official website. http://www.shypgh. gov.cn/gb/ypgh/ghlt/userobject1ai99.html (accessed 11 June 2006).

19. The website of the Shanhgai Nomad Club is http://www.hinomad. com; the website of the Common Wealth Management Project is http://www.almsdeed.com/

20. Shen, Y. 2003. War on Protecting Wetland in Cosmopolitan. Southern Weekly. 21 March 2003; Shen, Y. 2003. Exploring the Wetland of the Previous Jiangwan Airport. Southern Weekly, 21 March 2003; Shen, Y. Visiting Jiangwan. Southern Weekly, 21 March 2003; Bo, X. 2005. Exploring Jiangwan Airport. Wenhui Newspaper, 21 May 2005.

21. Experts from the Shanghai Science Museum, the Youth and Education Center of Science and Technology, and scholars from the Huadong Normal University Institute of Estuarine and Coastal Research participated in this meeting.

22. This was posted on the website of the SPMC http://72.14.207.104/ search?q=cache:FDnGd3Cq0z8J:www.shyp.gov.cn/polity/polity Content.jsp\%3Fct_id\%3D13886\%26sj_id\%3D708+\%E4\%B8\%8A \%Е6\%B5\%B7\%E5\%B8\%82\%E6\%94\%BF\%E5\%8D\%8F\%E3\%80 $\% 80 \%$ E6\%B1\%9F\%E6\%B9\%BE\&hl=zh-CN\&gl=nl\&ct=clnk\& cd=5\&lr=lang_zh-CN|lang_zh-TW|lang_en|lang_nl (accessed 4 June 2006).

23. This has not been the case for some issues that have been of greater political importance as for instance the Falun Gong, Taiwan, the Party, military developments, Tibet and foreign affairs. Environment is, however, clearly indicated as a less sensitive issue, although at times reporting is also clearly regulated and restricted, such as on the Three Gorges Dam, the Harbin disaster, and on spatial planning and land property rights.

24. The SEPA has recently changed its name to the Ministry of Environmental Protection of the People's Republic of China. Its authority has also increased with regard to environmental governance. 


\section{REFERENCES}

ACEF (All-China Environmental Foundation). 2006. Report on Environmental NGOs. Internal publication.

Cao, C. and R.P. Suttmeier. 2001. China's New Scientific Elite: Distinguished Young Scientists, the Research Environment and Hopes for Chinese Science. The China Quarterly 168: 960984.

Diani, M. 1990. The Italian Ecology Movement: From Radicalism to Moderation. In: Green Politics (ed. W. Rüdig), pp. 153-176. Edinburgh University Press, Edinburgh, UK.

Diani, M. and P.R. Donati. 1999. Organizational Change in Western European Environmental Groups: A Framework for Analysis. Environmental Politics 8: 13-34.

Economy, E. 2005. China's Environmental Movement. Testimony Before the Congressional Executive Commission on China Roundtable on Environmental NGOs in China: Encouraging Action and Addressing Public Grievances. US Government's Council on Foreign Relations. URL: http://www.cfr.org/publication/7770/ (accessed 3 February 2006).

Gamson, W.A. 1975. The Strategy of Social Protest. Dorsey Press, Homewood, Illinois, USA.

Gold, T., D. Guthrie and D. Wank (eds.). 2002. Social Connections in China: Institutions, Culture and the Changing Nature of Guanxi. Cambridge University Press, Cambridge, UK.

Guthrie, D. 1998. Declining Significance of Guanxi in China's Economic Transition. The China Quarterly 154: 254-282.

Ho, P. 2001. Greening Without Conflict? Environmentalism, Green NGOs and Civil Society in China. Development and Change 32: 893-921.

Ho, P. and R.L. Edmonds (eds.). 2008. China's Embedded Activism: Limitations and Constraints of a Social Movement. Routledge, London, UK; New York, USA.

Hwang, K. 1987. Face and Favor: The Chinese Power Game. American Journal of Sociology 92: 944-974.

Katz, D. and R. Kahn. 1966. The Social Psychology of Organizations. Wiley, New York, USA.

Landes, D.S. 1998. The Wealth and Poverty of Nations. W.W. Norton \& Co., New York, USA.

Lee, S. 2003. More Players on the Stage: New Trends in Shanghai's Water Pollution Control Policies. China Environment Series 6: $110-115$.

Lee, S. 2007. Environmental Movements and Social Organizations in Shanghai. China Information Vol. XXI (2): 269-297.

McCarthy, D.J. and M.N. Zald. 1973. The Trend of Social Movement in America: Professionalization and Resource Mobilization. General Learning Press, New Jersey, USA.
McCarthy, D.J. and M.N. Zald. 1977. Resource Mobilization and Social Movements: A Partial Theory. American Journal of Sociology 82: $1212-1241$.

Melucci, A. 1996. Challenging Codes: Collective Action in the Information Age. Cambridge University Press, Cambridge, UK; New York, USA.

Metzger, T. 2001. The Western Concept of the Civil Society in the Context of Chinese History. In: Civil Society: History and Possibilities (eds. S. Kaviraj and S. Khilnani), pp. 204-231. Cambridge University Press, Cambridge, UK.

Royo, A.G. 2000. The Power of Networking: Building Force to Navigate Cross-scale Turbulence Where Solo Efforts Fail. In: Indigenous Social Movements and Ecological Resilience: Lessons from Dayak of Indonesia (eds. J.B. Alcorn and A.G. Royo), pp. 73-83. Discussion paper series. World Wildlife Fund, Peoples, Forests and Reefs (PeFoR) Program, Washington DC, USA.

Staggenborg, S. 1988. The Consequences of Professionalization and Formalization in the Pro-Choice Movement. American Sociological Review 53: 585-606.

Wang, Y. 1987. Renqing Shengsuo, Mianzi Gongfu-Zhongguoren de Quanmou Zhidao [Face and Debt of Emotions-The Chinese Art of Power]. Journal of Teacher Zhang 1: 11-15.

Wu, F. 2002. New Partners or Old Brothers? GONGOs in Transitional Environmental Advocacy in China. China Environment Series 5: 45-58.

Xia, M. 2000. Political Contestation and the Emergence of the Provincial People's Congresses as Power Players in Chinese Politics: A Network Explanation. Journal of Contemporary China 9: 185-214.

Xie, L. and A.P.J. Mol. 2006. The Role of Guanxi in the Emerging Environmental Movement in China. In: Community and Ecology: Dynamics of Place, Sustainability and Politics (eds. A.M. McCright and T.N. Clark), pp. 269-292. Elsevier/JAI, Amsterdam, The Netherlands.

Yang, M. 1994. Gifts, Favors and Banquets: The Art of Social Relationships in China. Cornell University Press, New York, USA.

Yum, O.J. 1988. The Impact of Confucianism on Interpersonal Relationships and Communication Patterns in East Asia. Communication Monographs 55: 374-388.

Zhu, J. and P. Ho. 2008. Not Against the State, Just Protecting Residents Interests: An Embedded Movement in a Shanghai Neighborhood. In: Embedded Environmentalism: Limitations and Constraints of a Social Movement in China (eds. P. Ho and R.L. Edmonds), pp. 151-170. Routledge, London, UK; New York, USA.

Supervising editor: Daniel Brockington

Received 10 February 2008. Accepted 10 April 2008. Final 2 May 2008 . 